\title{
A New Species of the Hermit Crab Genus Pagurixus (Crus- tacea: Decapoda: Anomura: Paguridae) from Shallow Coral Reefs of Ishigaki Island, Ryukyu Islands
}

\author{
Tomoyuki Komai ${ }^{1}$ and Yoshitake Takada ${ }^{2}$ \\ ${ }^{1}$ Natural History Museum and Institute, Chiba, 955-2 Aoba-cho, Chuo-ku, Chiba, 260-8682 \\ Japan \\ komai@chiba-muse.or.jp \\ ${ }^{2}$ Ishigaki Tropical Station, Seikai National Fisheries Research Institute, 148-446 Fukai-Ota, \\ Ishigaki, Okinawa, 907-0451 Japan \\ yotak@affrc.go.jp
}

(Received 24 April 2006; Accepted 26 September 2006)

\begin{abstract}
Pagurixus nanus, a new species of pagurid hermit crab, is described from shallow coral reefs of Ishigaki Island, Yaeyama Islands, the Ryukyus. Most of the specimens were collected by using traps designed for sampling the fauna associated with coral rubble. The new species belongs to the $P$. anceps species group due to the lack of two ventral rows of setae on the ultimate segment of the antennular peduncle, but it appears unique in having one or two small, subproximal spines on the dorsal surfaces of the carpi of the second pereopods. Morphological characteristics suggest that $P$. nanus is close to $P$. anceps (Forest, 1954) and P. patiae Komai, 2006.

Key Words: Crustacea, Decapoda, Anomura, Paguridae, Pagurixus, new species, Ryukyu Islands, coral rubble, trap.
\end{abstract}

\section{Introduction}

Species of the pagurid genus Pagurixus Melin, 1939 are small hermit crabs distributed mainly in tropical to warm temperate waters in the Indo-Pacific. Recent studies have shown that the greatest species diversity of the genus is centered in the tropical and subtropical regions of the Western Pacific (Komai and Myorin 2005; Osawa et al. 2006; Komai 2006; Komai and Osawa in press), although several endemic representatives are known from southern Australia and New Zealand (McLaughlin and Haig 1984; de Saint Laurent and McLaughlin 2000). Pagurixus species are rather cryptic in habitat, occurring in crevices or holes of coral rocks, hiding under stones or rocks, or living in submarine caves, and careful collection is required for full documentation of the fauna of this genus in any given place. At present, 24 species are known, of which 17 have been reported from the Western Pacific. About half of the known species have been described in the last five years.

During the course of ecological study of the shallow coral reef community of Urasoko Bay, Ishigaki Island, southern Ryukyu Islands, several hermit crab species were obtained by trap sampling. The samples were submitted to the first author for identification. Three species of Pagurixus were found, one of which is here described as new, $P$. nanus. The other two species were $P$. carinimanus Komai 
and Osawa, 2006 and an undescribed species (see Komai and Osawa in press). The new species belongs to the $P$. anceps species group, characterized by the lack of distinct setal rows or series on the ventral surface of the ultimate segment of the antennular peduncle (Komai and Osawa 2006). The following 11 species are known in the group (cf. Komai and Myorin 2005; Osawa et al. 2006; Komai 2006): P. amsa Morgan, 1993, P. anceps (Forest, 1954), P. fasciatus Komai and Myorin, 2005, P. granulimanus Morgan, 1993, P. handrecki Gunn and Morgan, 1992, P. hectori (Filhol, 1883), $P$. jervisensis McLaughlin and Haig, 1984, P. kermadecensis de Saint Laurent and McLaughlin, 2000, P. longipes Osawa, Fujita and Okuno, 2006, P. patiae Komai, 2006, and P. stenops Morgan, 1993. Morphologically, $P$. nanus is closest to $P$. anceps and $P$. patiae. Differences between the new species and its related congeners are discussed below.

\section{Materials and Methods}

About half of the specimens of the new species selected for the description were collected in 2004 conducted on the back reef in Urasoko Bay in the northern part of Ishigaki Island, southern Ryukyu Islands, in traps designed for ecological study of the fauna associated with coral rubble. A trap consisted of a small basket $(21.5 \times 17.5 \times 6.0 \mathrm{~cm}$, mesh diameter $6 \mathrm{~mm})$ filled with coral rubble, i.e. dead Acropora spp., which was set $25 \mathrm{~cm}$ above the sea bottom at a depth of $1.5 \mathrm{~m}$. The traps were retrieved four weeks after being set. Other specimens were obtained from a similar trap set directly on the sea bottom in the same area in 1999. This trap was recovered 16 weeks after setting. In 2002, some specimens were obtained from the same sort of trap set directly on the sea bottom at a depth of $1 \mathrm{~m}$ for four weeks in coral lagoons at Hirakubo in the northern part of Ishigaki Island and at Miyara Bay in the southern part of the same island. These traps were recovered by enclosing them in plastic bags underwater and bringing them back to the laboratory within an hour to ice them and immobilize the animals. Additional specimens were obtained in 1999 from a dead coral colony of a tabular Acropora sp. (long axis $25 \mathrm{~cm}$, short axis $21 \mathrm{~cm}$ ) at a depth of $1 \mathrm{~m}$ on a back reef in Urasoko Bay. This coral, which died during a mass-bleaching event (Fujioka 1999), was collected by enclosing it in a plastic bag and breaking the intact colony away from the substrate with a hammer and chisel. The animals were extracted from the interstices of the coral rubble or the coral colony by washing the substrate with iced freshwater, and then they were preserved in $70 \%$ ethanol.

The type series of the new species is deposited in the Natural History Museum and Institute, Chiba (CBM), Japan. The shield length, abbreviated as SL, is measured from the tip of the rostrum to the midpoint of the posterior margin of the shield. For detailed observation of the surface structure on the integument, specimens (including removed appendages) were stained with methylene blue. Mouthparts are not illustrated because there are no differences in many mouthpart features within the genus (e.g., Morgan 1993; Komai and Asakura 1995). Terminology used in the description for the most part follows that of McLaughlin (2003), with the exceptions of the numbered thoracic sternites and the term dactylus (dactyli) for dactyl (dactyls). 


\section{Taxonomy}

Genus Pagurixus Melin, 1939

Pagurixus nanus sp. nov.

[New Japanese name: keshitsubu-hime-hon-yadokari]

(Figs 1-4)

Material examined. Holotype: male (SL $1.10 \mathrm{~mm}$ ), Urasoko Bay, Ishigaki Island, Ryukyu Islands, subtidal, 10 May 2004, coral rubble trap, coll. Y. Takada, CBM-ZC 8676.

Paratypes: 4 females (SL 0.60-0.91 mm), Urasoko Bay, subtidal, 23 March 1999, coral rubble trap, coll. Y. Takada, CBM-ZC 8677; 3 males (SL 0.75-0.94 mm), 2 females (SL 0.86, $0.95 \mathrm{~mm}$ ), and 2 ovigerous females (SL $0.86,0.93 \mathrm{~mm}$ ), same data as holotype, CBM-ZC 8678; 2 males (SL 0.98, $1.02 \mathrm{~mm}$ ), Urasoko Bay, $1 \mathrm{~m}$, dead tabular coral Acropora sp., 14 January 1999, coll. Y. Takada, CBM-ZC 8679; 2 males (SL 0.87, $0.93 \mathrm{~mm}$ ) and 1 female (SL $0.89 \mathrm{~mm}$ ), Hirakubo, Ishigaki Island, $1 \mathrm{~m}, 13$ May 2002, coral rubble trap, coll. Y. Takada, CBM-ZC 8680; 1 female (SL $0.67 \mathrm{~mm}$ ), Miyara Bay, Ishigaki Island, $1 \mathrm{~m}, 24$ June 2002, coral rubble trap, coll. Y. Takada, CBM-ZC 8681.

Description. Adult male. Shield (Fig. 1A) slightly longer than broad; anterior margin between rostrum and lateral projections concave; anterolateral margins sloping; posterior margin roundly truncate; dorsal surface with short setae anterolaterally. Rostrum triangular, distinctly overreaching lateral projections, relatively broad, terminating acutely. Lateral projections obtuse, each with small submarginal spinule.

Ocular peduncles (Fig. 1A) moderately stout, about 0.6 length of shield, each with few tufts of short setae on dorsomesial surface; middle part slightly inflated, subequal to or slightly greater than corneal width; corneas slightly dilated, corneal width about 0.3 of peduncular length. Ocular acicles subtriangular, each with small submarginal spine.

Antennular peduncles (Fig. 1A, B) overreaching distal margins of corneas by about 0.2 length of ultimate segments. Ultimate segment with 1 short seta at dorsolateral distal angle; ventral surface lacking longitudinal rows of setae. Basal segment with small spine on distal margin of statocyst lobe. Ventral flagellum with few short setae on lateral and mesial margins.

Antennal peduncles (Fig. 1A) slightly overreaching distal margins of corneas. Second segment with spinule at dorsomesial distal angle; laterodistal projection reaching midlength of fourth segment, terminating in simple spine. First segment unarmed on lateral face; ventromesial distal margin strongly produced, but unarmed. Antennal acicle arcuate, terminating in slender spine, overreaching base of cornea but not reaching its distal margin; mesial margin with few and sparse setae. Flagellum moderately long, more than 3.0 times as long as shield.

Right cheliped (Fig. 2A-C) massive, not particularly elongate. Chela subovate in dorsal view, about 1.7 times longer than broad. Dactylus about 0.8 of palm in length, terminating in small corneous claw; dorsomesial margin not delimited; surfaces with small granules; cutting edge with three rounded calcareous teeth and row of small corneous teeth interspersed with calcareous teeth. Palm slightly longer than carpus; convex dorsal surface covered with small, rounded granules; dorsolateral margin rounded; dorsomesial margin weakly delimited by short, 


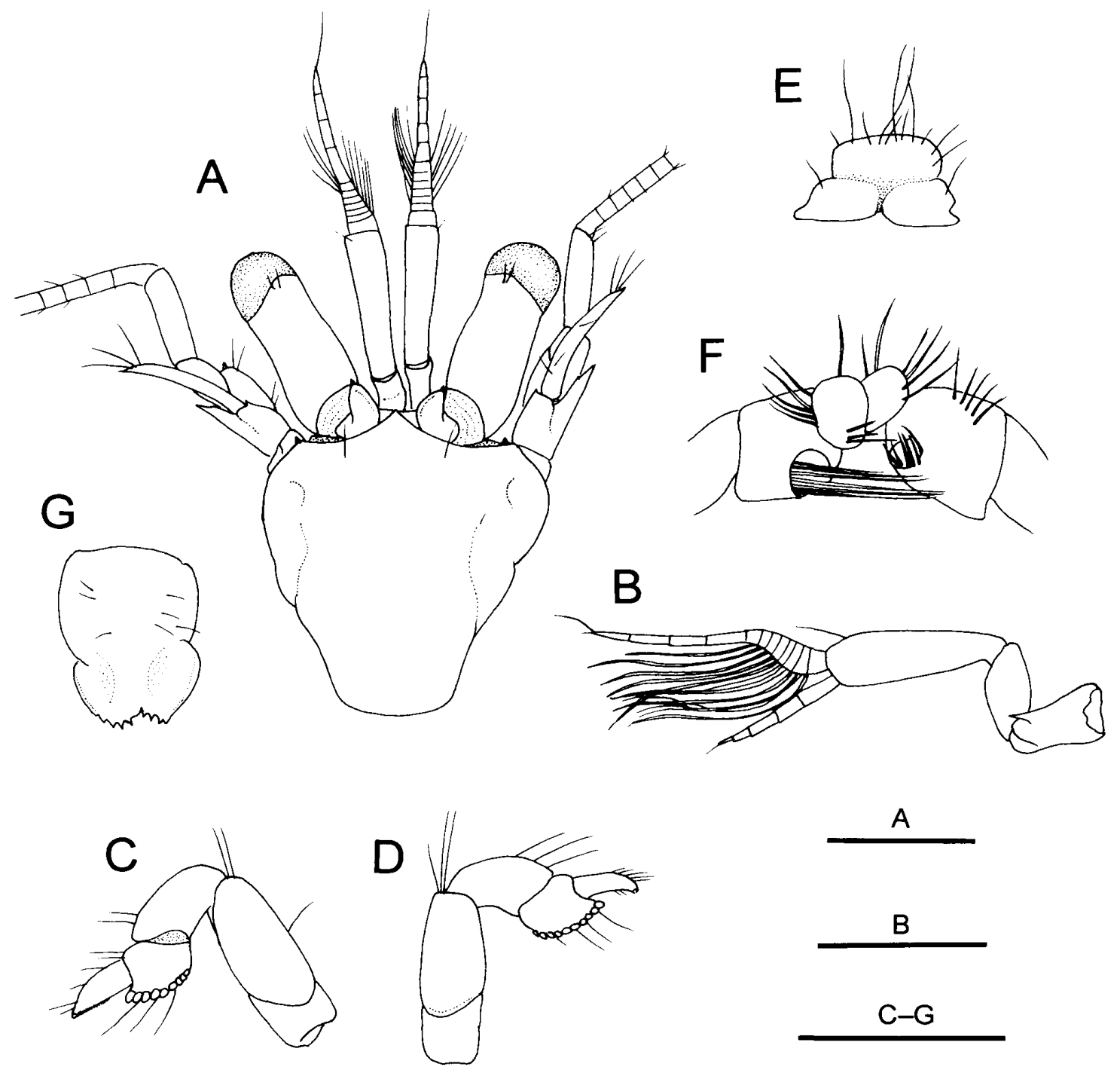

Fig. 1. Pagurixus nanus sp. nov., holotype male (SL $1.10 \mathrm{~mm}$ ) from Urasoko Bay, Ishigaki Island, CBM-ZC 8676. A, Shield and cephalic appendages, dorsal view; B, left antennule, lateral view; $\mathrm{C}$, left fourth pereopod, lateral view; D, right fourth pereopod, lateral view; E, sixth thoracic sternite, ventral view; F, coxae of fifth pereopods and eighth thoracic sternite; $\mathrm{G}$, telson, dorsal view. Scale bars $=0.5 \mathrm{~mm}$.

oblique ridges but not sharply carinate; lateral surface with scattered granules, mesial and ventral surfaces nearly smooth, occasionally with few short setae on ventral surface. Fixed finger with rounded dorsolateral margin, terminating in calcareous claw; cutting edge with row of low, blunt calcareous teeth and short rows of corneous teeth. Carpus subequal in length to merus, length of former about 1.1 times distal width; dorsolateral margin rounded; dorsomesial margin weakly delimited by row of 3 spines increasing in size distally and followed by single or double row of spiniform setae; all surfaces weakly granular, lateral surface lacking longitudinal ridge, ventral surface convex. Meral-carpal articulation lacking any pronounced clockwise rotation; dorsal surface of merus almost smooth, dorsodis- 

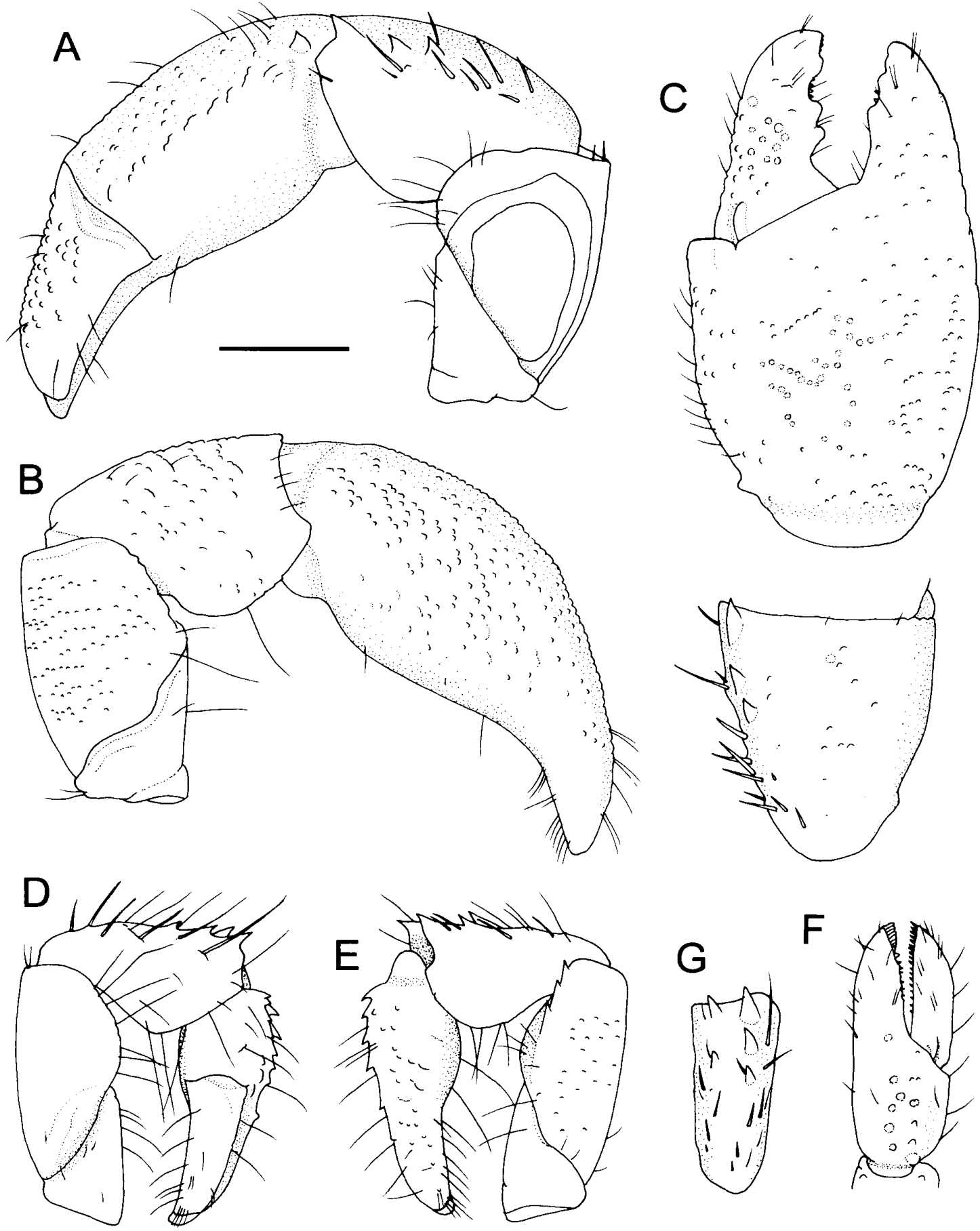

Fig. 2. Pagurixus nanus sp. nov., holotype male (SL $1.10 \mathrm{~mm}$ ) from Urasoko Bay, Ishigaki Island, CBM-ZC 8676. A, Right cheliped, mesial view; B, same, lateral view; C, chela and carpus of right cheliped, dorsal view; D, left cheliped, mesial view; E, same, lateral view; F, chela of left cheliped, dorsal view; G, carpus of left cheliped, dorsal view. Scale bar $=0.5 \mathrm{~mm}$. 
tal margin with few short setae; lateral face with scattered small granules, ventrolateral margin faintly tuberculate; mesial face smooth, convex ventromesial margin smooth; ventral surface smooth, only with few long setae. Ischium with smooth ventromesial margin; surfaces unarmed.

Left cheliped (Fig. 2D-G) moderately short and stout. Chela about 2.4 times longer than wide, about 1.2 times longer than carpus. Dactylus longer than palm, terminating in small corneous claw, with sparse tufts of setae on surfaces; dorsal surface smooth; cutting edge with row of small corneous teeth. Palm about half length of carpus; dorsal surface convex, with 2 irregular rows of small spines on midline; dorsolateral and dorsomesial margins not delimited; lateral surface with scattered granules, mesial and ventral surfaces nearly smooth, with scattered short to long setae on ventral surface. Fixed finger terminating in small corneous claw; cutting edge with row of small corneal teeth. Carpus moderately slender, somewhat compressed laterally, shorter than merus; length about 2.3 times distal width and 1.9 times height; dorsolateral margin with 2 small spines in distal half and row of spiniform setae in proximal half, dorsomesial margin with row of 3 spines and some spiniform setae; dorsodistal margin smooth; lateral face nearly perpendicular to dorsal surface, smooth, ventrolateral distal margin unarmed; mesial face also nearly smooth, with a few long setae; ventral surface convex, with a few long setae. Merus smooth on dorsal surface, dorsodistal margin unarmed; lateral surface with sparse minute granules, ventrolateral margin with 3 small spines in distal half; mesial face smooth, ventromesial margin smooth; ventral surface weakly convex, smooth, with few long setae. Ischium unarmed.

Ambulatory legs (Fig. 3E, F) moderately slender, similar on right and left. Dactyli about 0.9 length of propodi, 5.5-6.0 times longer than high, terminating in large corneous claws; dorsal surfaces each with few short setae; lateral and mesial faces smooth (Fig. 3G, H); ventral margins each with 5 moderately long corneous spines increasing in size distally. Propodi not tapering distally, 4.4-4.6 times longer than high; dorsal surfaces smooth, with sparse short setae; lateral faces smooth; ventral margins each with 1 or 2 corneous spinules, ventrodistal margins each with paired corneous spines. Carpi each with small dorsodistal spine; dorsal surfaces with 2 small spines mesially in proximal third (second pereopods) or with 1 tiny protuberance (third pereopods) (Fig. 3I, J), both with few setae. Meri with smooth dorsal and ventral margins each bearing sparse setae; lateral surfaces nearly smooth; ventrolateral distal margins each with small subdistal spine (second pereopod) or unarmed (third).

Fourth pereopods (Fig. 1C, D) subequal and similar on right and left. Dactylus moderately broad, straight (left), or slightly curved (right), terminating in small corneous claw; dorsal margin with short setae. Propodus with few setae on dorsal margins; mesial face nearly flat or slightly convex, with few short setae; propodal

Fig. 3. Pagurixus nanus sp. nov. A-D, Female paratype (SL $0.93 \mathrm{~mm}$ ) from Urasoko Bay, Ishigaki Island, CBM-ZC 8678; E-J, holotype male (SL $1.10 \mathrm{~mm}$ ) from same locality, CBM-ZC 8676. A, Right cheliped, lateral view; B, same, mesial view; C, chela of right cheliped, dorsal view; $\mathrm{D}$, carpus of right cheliped, dorsal view; $\mathrm{E}$, left second pereopod, lateral view; $\mathrm{F}$, left third pereopod, lateral view; $G$, dactylus of right second pereopod, mesial view; $H$, dactylus of left third pereopod, mesial view; I, carpus of right second pereopod, mesial view; J, carpus of left third pereopod, mesial view. Scale bars $=0.5 \mathrm{~mm}$. 

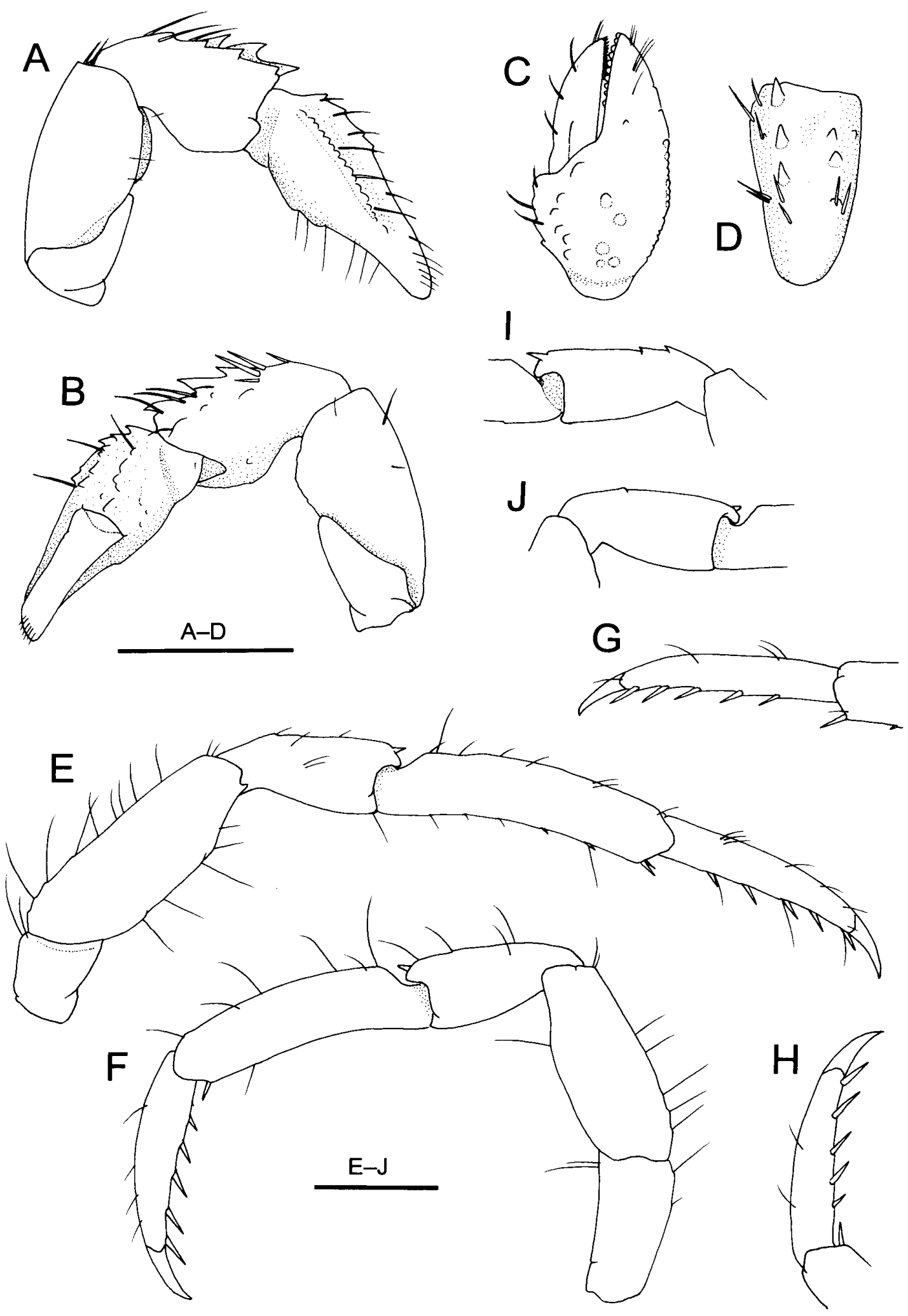
rasp of single row of corneous scales. Carpus without prominent tufts of setae on mesial face.

Anterior lobe of sixth thoracic sternite (Fig. 1E) subrectangular, with row of short to long setae on anterior margin. Eighth thoracic sternite (Fig. 1F) composed of 2 unequal, closely set, rounded lobes (right lobe larger than left); ventral surface of each lobe flattened, right lobe with tuft of setae posteriorly.

Coxae of fifth pereopods (Fig. $1 F$ ) slightly unequal; right one with prominent tuft of setae reaching to left coxa (Fig. 1G); no papilla-like protrusion of vas deferens. Left coxa with gonopore partially masked by tuft of short setae.

Telson (Fig. 1G) with terminal margins slightly oblique, bearing 3-5 small spines.

Female and young male. Generally similar to adult males except for right cheliped. Ocular peduncles $0.6-0.7$ of shield in length.

Chelipeds subequal, right one (Fig. 3A-C) slightly more robust than left. Chela of right cheliped subovate in dorsal view, 1.9-2.0 times longer than broad. Dactylus longer than palm, terminating in small corneous claw; dorsomesial margin not delimited; surfaces smooth; cutting edge with row of small corneous teeth. Palm shorter than carpus; convex dorsal surface with some small tubercles on midline and adjacent to dorsomesial margin; dorsolateral margin delimited by distinct granular ridge extending to midlength of fixed finger; dorsomesial margin weakly delimited by faintly tuberculate ridge; lateral face smooth, mesial face with few low tubercles. Fixed finger terminating in small corneous claw; cutting edge with row of broad corneous teeth. Carpus slightly shorter than merus, length 1.8-2.0 times distal width; dorsomesial margin with 3 moderately large spines in distal half; dorsolateral margin with 2 small spines; lateral face nearly perpendicular to dorsal surface, devoid of longitudinal ridge. Merus smooth on dorsal surface; ventrolateral and ventromesial margins smooth. Ischium unarmed.

Left cheliped similar in males and females. Chela 2.5-2.7 times longer than wide, about 1.2 times longer than carpus. Palm with 2 or 3 rows of small spines on dorsal midline. Carpus 0.7-0.8 times as long as chela; length 2.2-2.4 times distal width and 1.8-2.0 times height.

Ambulatory legs with dactyli about $0.9-1.0$ times as long as propodi, 5.0-6.0 times longer than high; ventral margins each with $4-6$ (frequently 5) moderately long corneous spines. Propodi not tapering distally, 4.0-4.6 times longer than high. Carpi each with 1 or 2 small spines on proximal 0.3 of dorsal surface (second pereopod) or unarmed or with 1 tiny protuberance (third). Females with unpaired left gonopore.

Color in life. See Fig. 4. Shield with scattered white and red dots on transparent background. Ocular peduncle with 3 transverse rows of brown spots on dorsal surface. Antennular peduncle banded; ultimate segment with 2 bands (middle band broader than proximal band, light brown, and basal band dark brown); penultimate segment with narrow brown band basally. Antennal peduncle generally transparent; fourth segment with brown transverse band distally; flagellum generally pale brown. Right cheliped white to pinkish; palm with tint of pale pink; carpus and merus with scattered pink dots or spots. Left cheliped similar in color to right cheliped; merus with dark brown transverse band distally. Ambulatory legs each with brown markings (bands or spots) on transparent background; dactylus with 1 band basally, and occasionally with small spot on dorsal surface medially; 

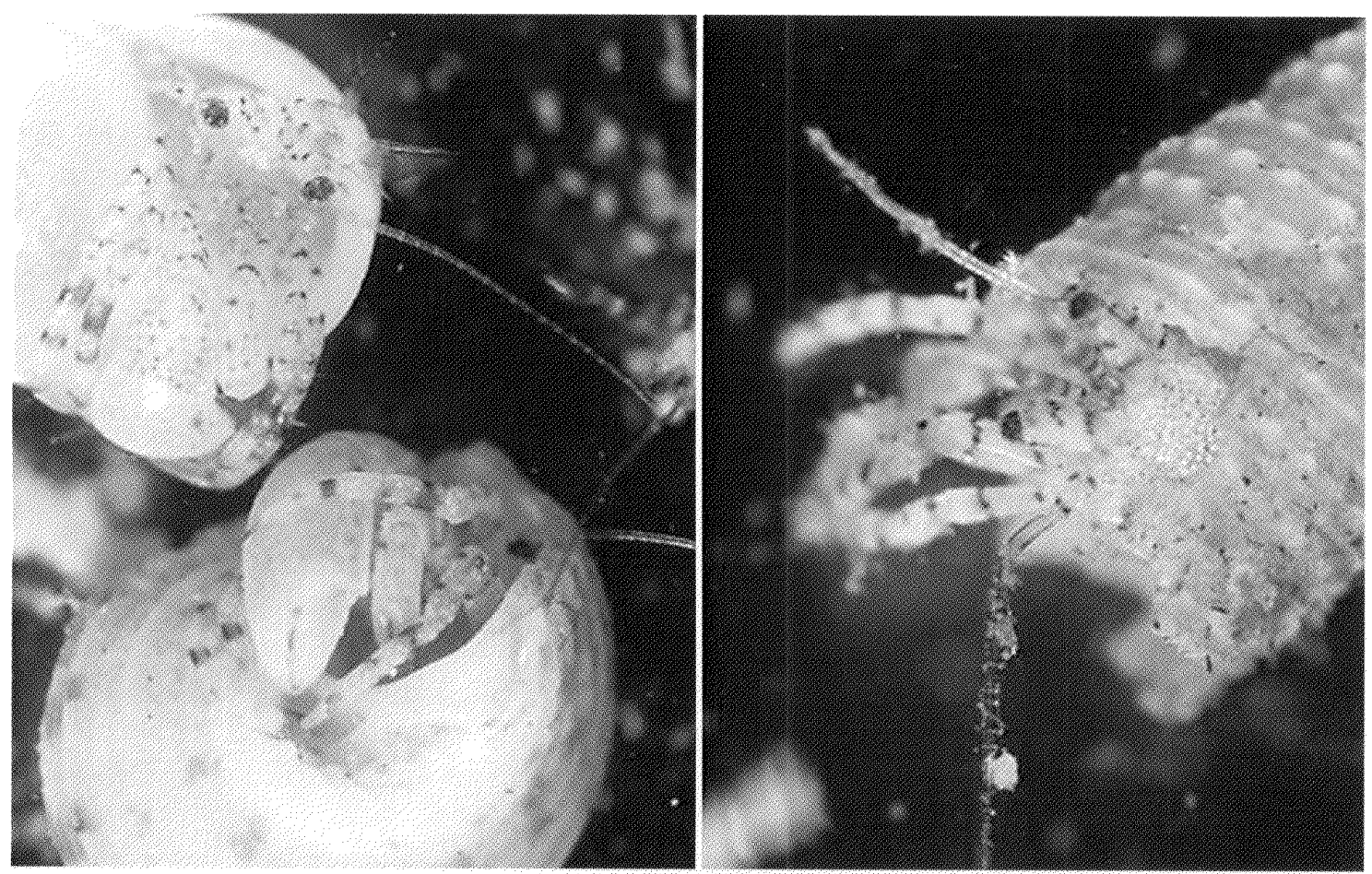

Fig. 4. Pagurixus nanus sp. nov. Living specimens, including paratypes of CBM-ZC 8679.

propodus with 2 bands, distal band occasionally obsolescent, proximal band broad, distinct; carpus with 2 spots on dorsal surface; merus with 1 or 2 dorsal spots or incomplete bands.

Size. Largest male SL $1.10 \mathrm{~mm}$; largest female SL $0.95 \mathrm{~mm}$, smallest ovigerous female SL $0.86 \mathrm{~mm}$.

Distribution. So far known only from shallow subtidal coral reefs of Ishigaki Island, Ryukyu Islands.

Etymology. From the Latin nanus, meaning dwarf, in reference to the small size of the new species; noun in apposition.

Remarks. The new species belongs to the Pagurixus anceps species group due to the absence of two setal rows or series on the ventral surface of the ultimate seg. ment of the antennular peduncle. Within the P. anceps species group, the possession of relatively few ventral spines on each ambulatory dactylus (four to six spines) links $P$. nanus to $P$. anceps and $P$. patiae. In other species of this species group, each ambulatory dactylus is armed with seven or more ventral spines (McLaughlin and Haig 1984; Morgan 1993; Komai and Myorin 2005). The new species appears unique among those of the $P$. anceps species group in having one or two small spines on the proximal half of the dorsal surface of each carpus of the second pereopod; in the other species, such spines are absent. Furthermore, $P$. nanus is readily distinguished from $P$. anceps itself by the less stout ambulatory legs, the non-produced ventrodistal margin of the carpus of the left third pereopod, the distinctly granular dorsal surface of the palm of the male right cheliped, and the presence of dorsomesial spines on the carpus of the male right cheliped. In $P$. anceps, the ventrodistal margin of the carpus of the left third pereopod is distinctiy 
produced, the palm of the male right cheliped is nearly smooth on the dorsal surface, and the carpus of the male right cheliped lacks dorsomesial spines (Forest 1954; McLaughlin and Haig 1984; personal observation). Pagurixus nanus is immediately distinguished from $P$. patiae by the similar fourth pereopods and the proportionally longer ambulatory dactyli (0.9-1.0 times as long as the propodus in $P$. nanus versus $0.7-0.8$ in $P$. patiae). The fourth pereopods of Pagurixus patiae are noticeably dissimilar, in which the left pereopod is longer than the right and the left dactylus bears a prominent tuft of setae.

Color in life is also useful in distinguishing $P$. nanus from $P$. anceps (personal observation), although the banded markings on the ambulatory legs are shared by the two species. Pagurixus nanus differs from $P$. anceps in the presence of the scattered pink spots or dots on the carpi and meri of the chelipeds.

Komai and Osawa (2006) has revealed that McLaughlin and Haig (1984) misidentified Pagurixus laevimanus (Ortmann, 1892). Specimens referred to P. laevimanus by McLaughlin and Haig (1984) actually represent an undescribed species of the $P$. anceps group (Komai and Osawa in press), whereas the true $P$. laevimanus is referred to the $P$. boninensis group. The undescribed species is also similar to the present new species, but it differs in the lack of dorsal spines or tubercles on the carpi of the second pereopods and the coloration in life (Komai and Osawa in press).

The new species may be the smallest among those assigned to this genus, although many species of Pagurixus are generally small in overall body size. The largest specimen of $P$. nanus, the male holotype, measures only $1.10 \mathrm{~mm}$ in SL; the ovigerous females range from 0.86 to $0.93 \mathrm{~mm}$ in SL. Congeneric species exceed $1.50 \mathrm{~mm}$ in SL in males (McLaughlin and Haig 1984; Morgan 1993; Komai and Myorin 2005; Komai and Osawa 2006; personal observation).

It is interesting to note that of the various collecting efforts by the authors, only the traps designed by the second author yielded many specimens of $P$. nanus. Two specimens were collected from a dead tabular coral just after an unusual mass-bleaching event of corals in 1998. In traps with coral rubble, the density of $P$. nanus sometimes reached up to 1000 individuals $/ \mathrm{m}^{2}$. Pagurixus nanus seems to prefer substrates consisting of dead coral skeletons, especially rubble. The presence of a cryptic fauna associated with coral rubble is strongly suggested. In order to fully understand coral reef species diversity, collecting efforts using various methods are necessary.

\section{Acknowledgments}

We express our thanks to Takuro Shibuno of the Ishigaki Tropical Station, Seikai National Fisheries Research Institute, for his help in field surveys. We also thank Masayuki Osawa of the University of Ryukyus and two anonymous reviewers for reviewing the manuscript. One of the authors (YT) was partly supported by Global Environment Research Fund (F-5) of the Ministry of Environment, Japan. 


\section{References}

Forest, J. 1954. Crustacés Décapodes Marcheurs des Iles de Tahiti et des Tuamotu. I. Paguridea (suite). Bulletin du Muséum National d'Histoire Naturelle, Paris (2) 26: 71-79.

Fujioka, Y. 1999. Mass destruction of the hermatypic corals during a bleaching event in Ishigaki Island, southwestern Japan. Galaxea JCRS 1: 41-50.

Komai, T. 2006. A new species of Pagurixus Melin, 1939 (Crustacea: Decapoda: Anomura: Paguridae) from the Ryukyu Islands, Japan. Zoosystema 28: 507-516.

Komai, T. and Asakura, A. 1995. Pagurixus nomurai, new species, and additional record of Pagurixus maorus (Nobili, 1906), hermit crabs from Kume-jima Island, the Ryukyus, Japan (Decapoda: Anomura: Paguridae). Journal of Crustacean Biology 15: 341-154.

Komai, T. and Myorin, E. 2005. A new species of Pagurixus (Crustacea: Decapoda: Anomura: Paguridae) from southern Japan. Zootaxa 876: 1-12.

Komai, T. and Osawa, M. 2006. A review of the Pagurixus boninensis species group, with descriptions of six new species (Crustacea: Decapoda: Anomura: Paguridae). Zootaxa 1214: $1-107$.

Komai, T. and Osawa, M. In press. A new species of the hermit crab genus Pagurixus Melin (Crustacea: Decapoda: Anomura: Paguridae) from the Indo-West Pacific. Raffles Bulletin of Zoology.

McLaughlin, P. A. 2003. Illustrated keys to families and genera of the superfamily Paguroidea (Crustacea: Decapoda: Anomura), with diagnoses of genera of Paguridae. Memoirs of $\mathrm{Mu}$ seum Victoria 60: 111-144.

McLaughlin, P. A. and Haig, J. 1984. A review of Pagurixus (Decapoda, Anomura, Paguridae) and descriptions of new species. Crustaceana 47: 121-148.

Melin, G. 1939. Paguriden und Galatheiden von Prof. Dr. Sixten Bocks Expedition nach den Bonin-Inseln 1914. Kongliga Svenska Vetenskapsakademiens Handlinger (3) 18: 1-119.

Morgan, G. J. 1993. Three new species of Pagurixus (Crustacea, Decapoda, Paguridae) from Western Australia, with notes on other Australian species. Pp. 163-181. In: Wells, F. E., Walker, D. I., Kirkman, H. and Lethbridge, R. (Eds) Proceedings of the Fifth International Marine Biological Workshop: the Marine Flora and Fauna of Rottnest Island, Western Australia. Western Australian Museum, Perth.

Osawa, M., Fujita, Y. and Okuno, J. 2006. Two new species of Pagurixus (Crustacea: Decapoda: Anomura: Paguridae) from submarine caves of the Ryukyu Islands, southwestern Japan. Zootaxa 1148: 27-45.

Saint Laurent, M. de and McLaughlin, P. A. 2000. Superfamily Paguroidea Family Paguridae. Pp. 104-209. In: Forest, J., Saint Laurent, M. de, McLaughlin, P. A. and Lemaitre, R. The Marine Fauna of New Zealand: Paguridea (Decapoda: Anomura) Exclusive of the Lithodidae. NIWA Biodiversity Memoir 114. NIWA, Wellington. 